\title{
Cuban Blue Anole (Anolis allisoni) Copulation Interrupted by Another Male
}

\author{
Rafael Borroto-Páez ${ }^{1}$ and Denise Reyes Pérez ${ }^{2}$ \\ 1Sociedad Cubana de Zoología, AP 11900, La Habana, Cuba (borroto@yahoo.com) \\ ${ }^{2}$ Instituto de Geografía Tropical, Calle F entre 13 y 15, Vedado, La Habana, Cuba
}

$\mathrm{T}$ The Cuban Blue Anole (Anolis allisoni Barbour 1928), is an abundant species with a wide distribution across much of Cuba - absent only in the extreme west in Pinar del Rio Province and the western part of Artemisa Province (RodriguezSchettino 2013). This species also occurs along the Caribbean coast on the Islas de la Bahia (Honduras), Isla Cozumel (Mexico), and the offshore islands of Belize (Henderson and Powell 2009). It also has been introduced in Florida (Krysko et al. 2015). The species often functions as a human commensal and frequently is encountered in buildings and gardens. Despite its abundance, its ecology and reproductive behavior has not been thoroughly studied. Ruibal (1967) described courtship, Silva-Lee (1982) determined that maximum reproductive activity occurred during the rainy season, and Kwet (1995) observed several females in a single male's territory.

In the coastal region near the towns of Marti, Matanzas Province, and Corralillo, Villa Clara Province, A. allisoni is almost ubiquitous in residential gardens, buildings, and cultivated areas. In Ategorrieta (22 $56{ }^{\prime} 20^{\prime \prime N}, 80^{\circ} 56^{\prime} 58^{\prime \prime}$ W), 2 $\mathrm{km} \mathrm{W}$ of Marti, we observed a male interrupting a pair of anoles in copulation. At about $0940 \mathrm{~h}$ on 6 August 2014, we observed a pair of mating $A$. allison $i$ with the male holding the female and remaining essentially motionless for 10-15 minutes (Fig. 1A). Another male left a perpendicular wall about 3 $\mathrm{m}$ away and approached the copulating pair, moving in intervals interrupted by pauses of several seconds (Fig. 1B). Once it was within $25 \mathrm{~cm}$ (Fig. 1C), the "intruder" attacked and bit the copulating male twice (Fig. 1D-E), causing it to release the female. All three lizards subsequently left, all moving in different directions.

Although we considered the male in copula to be the resident and the attacking male an "intruder," we could not confirm that. However, the fact that the "intruder" came from a distance of more than $3 \mathrm{~m}$ lends some supports to the supposi-
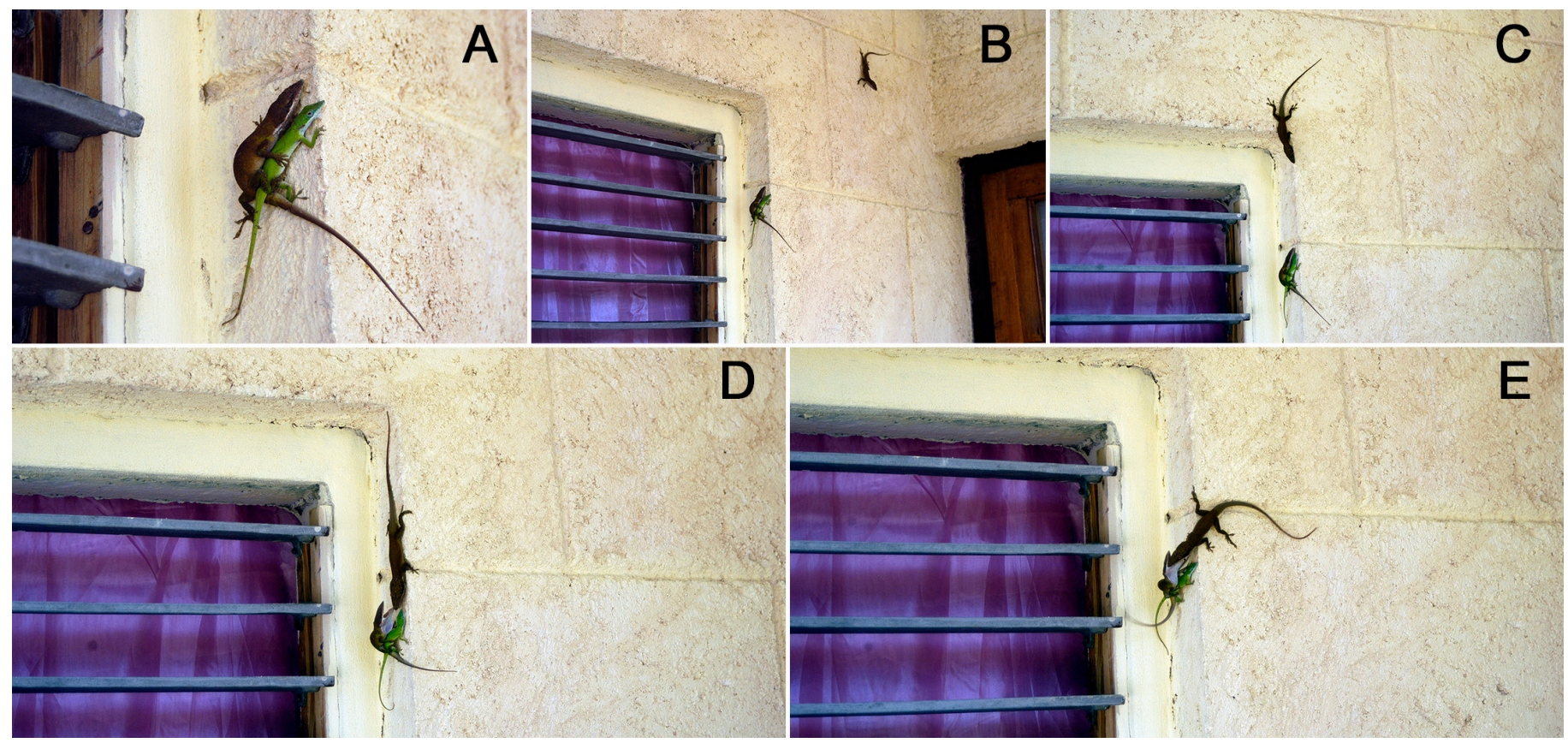

Fig. 1. A pair of Cuban Blue Anoles (Anolis allisoni) in copula (A) approached by a presumptive "intruder" (B-C) that attacks and bites the "resident" male (D-E), effectively interrupting mating.

Copyright ( 2019. Rafael Borroto-Páez. All rights reserved. 
tion that it was not the resident. Both males were of comparable size, with the "resident" only slightly larger. When we described the event to local residents, they indicated that this sometimes happens, suggesting that this is not a rare occurrence.

Parmerlee et al. (1992) described similar behavior in an introduced population of Anolis porcatus in the Dominican Republic, but the males involved were less aggressive. Implications of such aggressive intraspecific male-male behavior are unknown but a complex behavior with an apparently high energetic cost is presumably related to the defense and potential usurpation of territories and resident females.

\section{Acknowledgement}

We thank Boris A. Fabres, Environmental Protection in the Caribbean (EPIC), for reviewing an early version of the manuscript and providing useful suggestion that improved it.

\section{Literature Cited}

Henderson, R.W. and R. Powell. 2009. Natural History of West Indian Reptiles and Amphibians. University Press of Florida, Gainesville, Florida.

Krysko, K.L., C.A. MacKenzie-Krysko, L.L. Connor, Y.U. Alfonso, and L.P. Nunez. 2015. The Cuban Blue Anole, Anolis allisoni Barbour 1928 (Squamata: Dactyloidae), a new nonnative lizard introduced to Florida. Reptiles o Amphibians 22: 128-131.

Kwet, A. 1995. Amphibien und reptilian auf Kuba. Die Aquarien- und Terrarien Zeitschrift (DATZ) 48: 662-665.

Parmerlee, J.S., Jr., R. Powell, D.D. Smith, and A. Lathrop. 1992. Unusual behavior in the Cuban Green Anole, Anolis porcatus (Sauria: Polychridae). Bulletin of the Chicago Herpetological Society 27: 118.

Rodríguez Schettino, L., C.A. Mancina, and V. Rivalta. 2013. Reptiles of Cuba: Checklist and geographic distributions. Smithsonian Herpetological Information Service 144: 1-96.

Ruibal, R. 1967. Evolution and behavior in West Indian Anoles, pp 116-140. In: W.W. Milstead (ed.), Lizard Ecology. A Symposium. University of Missouri Press, Columbia, Missouri.

Silva Lee, A. 1984. Chipojo, Bayoyas y Camaleones. Editorial Científico Técnica, La Habana, Cuba. 